Teologia Praktyczna 20(2019)

doi: $10.14746 /$ tp.2019.20.10

ORCID: 0000-0001-7514-5536

WŁADYSŁAW CHAIM

\title{
Akceptacja treści przekonań religijnych a religijne style myślenia i osobowość. Badania empiryczne studentów
}

Temat psychologicznych uwarunkowań akceptacji treści religijnego nauczania (treści wiary) jest obecny w psychologii religii, niemniej nadal wymaga badań. Inspirują do tego m.in. sondaże relacjonujące zmiany przekonań religijnych w populacji. Literatura (badania kościelne i pozakościelne) dostarcza wyników badań monitorujących to, „w co” wierzą chrześcijanie, katolicy (CBOS 2015; Jak to jest z wiara Polaków 2018). Odpowiedź na pytanie o uwarunkowania tych zmian jest ważna ze względu na selektywność w postawie wobec systemu religijnych wierzeń oraz zmiany jej intetensywności. $\mathrm{Z}$ drugiej strony, potrzebne są badania nad procesem dojrzewania do optymalnej postawy wiary $\mathrm{w}$ jej aspekcie doktrynalnym, w wymiarze poznawczym. W związku z tym, zależy nam na sprawdzeniu, jakie procesy psychologiczne wiążą się z różnicami w akceptacji chrześcijańskiego, katolickiego credo, a także, jakie postawy przekonaniowe towarzyszą niepełnemu, niespójnemu ustosunkowaniu się do obowiązującej doktryny Kościoła?

Z punktu widzenia zarówno psychologii religii, jak i teologii pastoralnej ważna jest wiedza o tym, „w co" wierzą chrześcijanie (fides quae) oraz „jak wierzą" (fides qua) (por. Martos i in. 2010, s. 863-868). Na temat zakresu i stopnia akceptacji doktryny religijnej można spotkać literaturę dotyczącą niespójności (vs spójności) religijnych przekonań (np. Chaim 1991; Zieliński 2006; Radoń 2018). Istnieją także badania związane raczej z procesem rozwoju przekonań religijnych, które pozwalają na obserwację zmian religijnej postawy (Hutsebaut 1996, s. 48-66; Zarzycka 2012, s. 344-353). Dostarczają one wiedzy na temat tego, ,jak", w jakim stylu ludzie wierzą, przyjmują bądź 
odrzucają pewien zespół poglądów dotyczących Boga, Biblii, człowieka itp. Trudniej jest natomiast spotkać badania, które łączyłyby obydwa podejścia, tzn. problematykę akceptacji treści wiary ze stylami religijnego myślenia. Badania relacjonowane $\mathrm{w}$ artykule łączą powyższe podejścia $\mathrm{w}$ celu lepszego zrozumienia asercji (akceptacji vs odrzucania) konkretnych aspektów treści religii (wiary) chrześcijańskiej, zwłaszcza katolickiej. Przy okazji, będzie także badane, czy i w jakim stopniu akceptacja doktryny religijnej jest powiązana $\mathrm{z}$ osobowością.

\section{Religijność a osobowość}

\section{Religijność a typy psychologiczne}

Badania ich wzajemnych powiązań prowadzili m.in.: Meyer (1966), Gerhardt (1983, s. 47-53), Lee (1986) oraz Delis-Bulhoes (1990, s. 25-33). W postawie ukierunkowanej na chrześcijaństwo nie stwierdzono różnic między typami ekstrawertywnymi i introwertywnymi ani między typami myślowymi i uczuciowymi (por. Fearn i in. 2001, s. 341-348; Francis i in. 2004, s. 15-33). $\mathrm{W}$ innych badaniach nie stwierdzono różnicy w postawie wobec chrześcijaństwa także między typami myślowymi i typami uczuciowymi (por. Fearn i in. 2001; Francis i in. 2004). W kolejnym z badań okazało się, że typy uczuciowe miały bardziej pozytywne nastawienie do chrześcijaństwa niż typy myślowe (intelektualne) (por. Jones i Francis 1999, s. 105-109). Typy uczuciowe wyrażały mocniejszą wiarę w uzdrowienia niż typy myślowe (por. Village i Francis 2005, s. 74-89). Jeżeli chodzi o opis stworzenia w Księdze Rodzaju, preferujący myślenie częściej wybierali interpretację literalną niż preferujący uczucie (por. Village i Francis 2005; Village 2012, s. 955-968; 2014, s. 72-82).

Wśród aktywnych wierzących stwierdzono istotne korelacje typu percepcyjnego z religijnym konserwatyzmem oraz typu intuicyjnego z liberalizmem (Delis-Bulhoes 1990). Typy zmysłowe i myślowe są bardziej skłonne do wyrażania tradycyjnych przekonań religijnych niż typy intuicyjne i uczuciowe (por. Francis i Jones 1998, s. 5-11; Chaim 2017, s. 31-45). Typy zmysłowe bardziej wyraziście oddzielają rzeczywistość sakralną od świeckiej niż typy intuicyjne, które podkreślają nieokreśloność Boskości (Boga). Dla typów zmysłowych religijne wątpliwości są bardziej przykre, a zasady bardziej ważne, w przeciwieństwie do typów intuicyjnych, także bardziej otwartych na zmiany (por. Ross i in. 1996, s. 263-279). Typy zmysłowe ujawniają bardziej pozytywną postawę w stosunku do chrześcijaństwa niż typy intuicyjne (por. Francis i in. 2003, s. 89-90; Fearn i in. 2001). Typy percepcyjne wykazują mniejszą tolerancję na niepewność niż preferujący intuicję (por. Jones i Francis 1999). 
Typy sensytywne wśród świeckich anglikanów wykazują bardziej konserwatywne poglądy na temet Biblii i teologii niż typy intuicyjne, preferując dosłowną interpretację Biblii (por. Village 2005, s. 243-254). Preferencja zmysłowa u zmysłowych łączy się w większym stopniu z interpretacją dosłowną treści opisu stworzenia w Księdze Rodzaju, podczas gdy preferencja intuicyjna łączy się w większym stopniu z jego interpretacją symboliczną (por. Village 2014, s. 72-82). Ogólnie, poglądy biblijne (konserwatyzm - liberalizm) były bardziej powiązane z procesami postrzegania (zmysłowość - intuicja) niż z procesami wartościowania (myślenie - uczucie), natomiast w przypadku przekonań dogmatycznych było odwrotnie (por. Village 2012; Chaim 2017). Sądzący wskazywali religię jako strukturę dla wiary i praktyk, natomiast perceptywni jako źródło doświadczenia (por. Ross i in. 1996). Sądzący przejawiali bardziej pozytywną postawę w stosunku do chrześcijaństwa niż perceptywni (por. Fearn i in. 2001).

\section{Religijność a samoocena (poczucie własnej wartości)}

Z perspektywy wiary chrześcijańskiej, poczucie własnej wartości jest ważnym wymiarem osobowości; chrześcijanin bowiem otrzymuje „odkupioną” przez Chrystusa tożsamość „dziecka Bożego” (Rz 7; por. Engelsma 1990). Fisher (1992), analizując wybrane elementy doktryny dotyczące ludzkiej natury, Boga, Chrystusa, i Ducha Świętego, wykazywał, że są one podstawą dla zdrowego poczucia własnej wartości, gdyż dostarczają ram, umożliwiających korekty zbyt wysokiego lub zbyt niskiego poczucia własnej wartości. Idea tego, że religijność może być w służbie samooceny, została wprowadzona przez Jamesa, była popierana przez Allporta oraz korygowana przez Batsona i Stocksa (por. Sedikides i Gebauer 2018). Prężyna (1981, s. 135) stwierdził wyraźnie, że obraz siebie jednostki pozostaje w istotnym związku z jej postawą religijną. Z przeglądu literatury opracowanego przez Jonesa i Francisa (1996, s. 180-205) wynika, że samoocena (self-esteem) jest fenomenem złożonym i wielowarstwowym. Sugerowali oni, że tradycja chrześcijańska wpływa raczej wspierająco na samoocenę u młodzieży. W badaniach związku między religijnością a stosunkiem do własnej osoby trudno jednak ustalać wzajemne powiązania ze względu na wieloaspektowość obydwu zmiennych,wielość ich definicji oraz metod, które rzadko są kompatybilne. Dlatego korelacjom między samooceną a religijnością daleko jest do jednoznaczności (por. Jennings 2003, s. 182). Poniższa relacja zawiera jedynie przybliżony obraz efektów badań nad powiązaniem obu zmiennych.

W literaturze można spotkać badania, w których nie stwierdzono istotnych powiązań między religijnością (m.in.: orientacja religijna, praktyki re- 
ligijne, stosunek do religijnej tradycji, przekonania religijne, pojęcie Boga) a samooceną; warto zauważyć, że przeważnie są to badania prowadzone na grupach młodzieży (por. Murphy 2009; Donahue i Benson 1995, s. 145-160; Bhalla $\mathrm{i}$ in. 2003, s. 157-162; Williams 2012, s. 11-17; Jennings 2003, s. 182; Smither i Walker 2015, s. 647-662; Taylor 2018). Searles (2012) zwróciła uwagę, że wyższy poziom samooceny u wierzących występuje w krajach (uniwersytetach), gdzie religia ma dla kultury centralne znaczenie, natomiast w środowiskach, gdzie religia nie ma znaczenia, samoocena wierzących jest niższa niż niewierzących. Pewne badania ujawniły, że dorastający, bardziej religijni, uzyskiwali wyższe wyniki w samoocenie (por. Hamm 1976, s. 1196-1198; Smith i in. 1979, s. 51-60; Bagley i Mallick 1997, s. 89-92; Agu i in. 2013, s. 46-48). Na poziom samooceny uczniów miały wpływ wiara religijna oraz znaczenie religii (religioussaliency) (Mather 2015, s. 69-97). Jednakże w niektórych badaniach stwierdzono, że uczniowie bardziej religijni uzyskiwali gorsze wyniki w poziomie samooceny ${ }^{1}$. Badanie wśród dorastających w Wielkiej Brytanii wykazało, że praktyki religijne młodzieży nie mają związ$\mathrm{ku}$ z samooceną. Jedynie osobista lektura Biblii oraz ojcowskie zaangażowanie w kościelne praktyki religijne ujawniło nieznaczny, choć istotny, negatywny wpływ na samoocenę (por. Hills i in. 2006, s. 61-76). Nie uzyskano jednoznacznych informacji, czy płeć ma związek z relacjami między samooceną a religijnością młodzieży (por. Moore i Stoner 1977, s. 55-56; Smith i in. 1979, s. 51-60). Z badań wśród dorosłych w starszym wieku, które przeprowadził Krause (1995, s. 236-246), wynikała nieliniowa relacja w kształcie litery „U”, tzn, że u osób w podeszłym wieku samoocena jest zarówno najwyższa, jak i najniższa; najwyższa wśród praktykujących intensywnie, a najniższa wśród wykazujących umiarkowany poziom religijności. Poza tym, samoocena wykazuje tendencję do obniżania się u osób $\mathrm{z}$ niskim poziomem religijnego zaangażowania bardziej niż u tych, którzy mają umiarkowany poziom religijnego zaangażowania. Jeszcze inne badania doprowadziły do konstatacji, że pozytywny związek między samooceną a religijnością jest współdeterminowany przez czynniki wieku i płci (por. Liu 2013, s. 15-28; Krause 1995, s. 236-246). Ponieważ interakcja religii z ,ja”człowieka jest niewątpliwie ważna i długotrwała, dlatego ważne jest także kontynuowanie obserwacji wzajemnego oddziaływania religijności i samooceny (por. Sedikides i Gebauer 2018).

${ }^{1}$ Por. https://ohssocialscienceresearch.wordpress.com/2015/12/10/examining-the-relationshipbetween-religiosity-and-self-esteem-among-adolescents-by-zachary-koval-2/ [dostęp:19.07.2018]. 


\section{Przekonania religijne a cechy osobowości}

W czynnikowej teorii osobowości Eysncka (PEN) osobowość można opisać w trzech wymiarach: 1) introwersja (dyspozycja do bycia cichym, wycofanym, refleksyjnym, unikającym ryzyka) vs ekstrawersja (dyspozycja do bycia towarzyskim, przyjaznym, impulsywnym, chętnym do podejmowania ryzyka), 2) neurotyzm vs zrównoważenie emocjonalne (stabilność vs niestabilność emocjonalna), 3) psychotyzm (tendencja do izolacji, niewrażliwości, braku troski o innych, sprzeciwianie się powszechnie akceptowalnym normom społecznym) (por. Pervin i Oliver 2002, s. 239nn).

W pewnych badaniach stwierdzono negatywną korelację między religijnością a ekstrawersją (por. Francis i in. 1981, s. 101-104). Jednak w wielu innych badaniach korelacji między tymi zmiennymi nie stwierdzono (por. Lewis i Maltby 1995, s. 293-295; Wilcox i Francis 1997, Fearn i in. 2003, s. 819-822; s. 48--56; Williams i Francis 2006, s. 292-294). Również dorastający introwertycy nie byli bardziej religijni od ekstrawertyków, co nie potwierdziło wyników wcześnieszych badań (por. Williams i in. 2005, s. 77-79). Stwierdzano także brak korelacji między neurotyzmem a religijnością (por. Francis i Jackson 2003, s. 87-100). Natomiast u dorosłych praktykujących ze stabilnością emocjonalną powiązane były wysokie wyniki w „konserwatywnych” przekonaniach chrześcijańskich (Francis i Jones 1998). Dosyć zgodnie badania wykazują negatywne relacje między pomiarem psychotyzmu a różnymi pomiarami religijności (por. Francis 1992, s. 645-662; Maltby 1997, s. 827-831; Wilcox i Francis 1997; Fearn i in. 2001; Williams i Francis 2006, s. 292-294). Z badań na próbie chrześcijan prawosławnych wynika, że wysokie wyniki w psychotyzmie były powiązane z niższymi wynikami w religijności tylko u mężczyzn (por. Youtika i in. 2007, s. 71-74). Dane z badań Francisa (1991, s. 791-794) pokazały, że u wiernych praktykujących powiązanie między osobowością a religijnością może funkcjonować inaczej niż u populacji generalnej. $Z$ wielu badań, także podłużnych oraz międzykulturowych, wynika, że z uwzględnieniem wieku (dzieci, dorastający, dorośli oraz starsi dorośli), religijność jest negatywnie skorelowana $\mathrm{z}$ psychotyzmem oraz zasadniczo nieskorelowana z ekstrawersją i neurotyzmem (por. McCullough i in. 2002).

Do diagnozowania cech osobowości, które ludzie uważają za szczególnie ważne w życiu został stworzony pięcioczynnikowy model osobowości (PMO). Zakłada się w nim, że wyodrębnione w nim wymiary stanowią adekwatną reprezentację cech osobowości. Są to: neurotyzm (N), ekstrawersja (E), otwartość (O), ugodowość (U), sumienność (S) (por. Pervin i Oliver 2002, s. 268nn).

Badania wykonane metodą PMO wśród wyznawców islamu dały negatywne korelacje między religijnością a neurotyzmem oraz pozytywne między religijnością a ekstrawersją, ugodowością, sumiennością oraz otwartością na do- 
świadczenia (por. Khoynezhad i in. 2012, s. 82-86; Abdel-Khalek i Al-Jawhary 2017). Badania wśród chrześcijan wykazały, że ugodowość i sumienność były pozytywnie związane z religijnym zaangażowaniem i wewnętrzną orientacją religijną (por. McCullough i in. 2002). Inne badania potwierdzają doniosłość sumienności jako predyktora religijności. Zwraca się uwagę na to, że dorastający, emocjonalnie niestabilni, mogą łatwiej uzyskiwać poziom religijności podobny do tego, który charakteryzuje ich rodziców (por. McCullough i in. 2002). Z meta-analiz wyników badań nad religijnością w związku z osobowością wynika, że religijność jest związana jedynie z niskim psychotyzmem (lub wysoką ugodowością i sumiennością), a bez związków z pozostałymi czynnikami Eysencka bądź czynnikami PMO. Poszukiwania te pokazały ponadto, że oprócz ugodowości i sumienności, religijność jest związana z ekstrawersją (por. Saroglou 2002, s. 15-25). W korelacyjnym studium powiązań osobowości z religijnością stwierdzono silny pozytywny związek między neurotyzmem a religijnością, natomiast negatywny między religijnością a ekstrawersją. Niezbyt silny negatywny związek wystąpił między religijnością a otwartością. Ugodowość i sumienność były w niewielkim stopniu powiązane z religijnością (por. Sontakke 2017, s. 55-58).

W kwestii związku między PMO a stylami religijnego myślenia, na flamandzkiej próbie młodzieży w okresie późnej adolescencji stwierdzono, że wymiar odrzucanie vs. włączanie transcendencji nie jest powiązany z żadnym z wymiarów osobowości, podczas gdy wymiar interpretacji literalnej vs. symbolicznej był mocno powiązany z otwartością na doświadczenia i nieznacznie z ugodowością. Relacja między otwartością na doświadczenie i wymiarem literalny vs. symboliczny był silnie zapośredniczony przez informacyjny styl tożsamości. Po uwzględnieniu otwartości na doświadczenia, ugodowość przestała być ważną determinantą dla wymiaru literalny vs. symboliczny (por. Duriez i in. 2004, s. 877-910; Duriez i Soenens 2006, s. 119-135).

Przedstawione poniżej wyniki badań stanowią próbę odpowiedzi na pytania, czy istnieje zależność między zróżnicowany stosunkiem do treści wiary chrześcijańskiej a zmiennymi religijności i osobowości, oraz czy istnieje związek - a jeśli tak, to w jakim obszarze - między stosunkiem do treści religijnych przekonań a religijnymi stylami poznawczymi, a także innymi zmiennymi religijności i osobowością? 


\section{Metodologia}

\section{Hipotezy}

Hipoteza 1. Istnieje powiązanie między stosunkiem do treści chrześcijańskiego nauczania a religijnością, tzn.:

Hipoteza 1a: Istnieje powiązanie między stopniem akceptacji przekonań religijnych (podstawowych, kościelnych, naturalnych) a stylami religijnego myślenia.

Hipoteza 1b: Istnieje powiązanie między stopniem akceptacji przekonań religijnych a oceną własnej religijności (znajomość doktryny, emocjonalna więź, poziom praktyk, związek życia moralnego z religią, osobisty związek z religią), doświadczeniem nawrócenia oraz częstotliwością korzystania z Biblii.

Hipoteza 2: Istnieje związek między stopniem akceptacji przekonań religijnych a zmiennymi osobowości, tzn.:

Hipoteza 2a: Istnieje związek między stopniem akceptacji przekonań religijnych a preferencjami psychologicznymi: E-I, S-N, T-F, J-P.

Hipoteza 2b: Istnieje związek między stopniem akceptacji przekonań religijnych a obrazem siebie (samooceną).

Hipoteza 2c: Istnieje korelacja pomiędzy stopniem akceptacji przekonań religijnych a cechami osobowości, takimi jak: ekstrawersja, ugodowość, sumienność, stabilność, otwartość.

\section{Zmienne}

Zmienna zależna (objaśniana): akceptacja treści przekonań religijnych w trzech wymiarach Skali Spójności Przekonań Religijnych: Przekonania Podstawowe (treść formułuje prawdy wiary religii chrześcijańskiej poznawane w objawieniu biblijnym), Przekonania Kościelne (treść dotyczy Kościoła jako autorytetu religijnego oraz instytucji pośredniczącej w życiu religijnym wierzącego), Przekonania Naturalne (treść wyraża prawdy wiary i zasady moralne uznawane w oparciu o refleksję).

Zmienne niezależne (objaśniające):

- Religijne style poznawcze. Koncepcja religijnych stylów poznawczych Wulffa opisuje możliwe sposoby myślenia religijnego w przestrzeni dwuwymiarowej: włączania vs wyłączania transcendencji oraz - posta- 
wie literalnej vs symbolicznej. W połączeniu wymiary te tworzą przestrzeń do opisu czterech potencjalnych religijnych stylów poznawczych, którymi są: literalna afirmacja, literalne odrzucenie, symboliczne odrzucenie i symboliczna afirmacja. Zostały one zoperacjonalizowane w skali PCBS jako: ortodoksja, krytyka zewnętrzna, historyczny relatywizm i wtórna naiwność (por. Wulff 1991; Hutsebaut 1996, s. 48-66; Śliwak i Zarzycka 2010, s. 67-85).

- Samoocena religijności. Samoocena religijności wyrażona w autodeklaracji służy głównie do opisu grup. Dotyczy oceny własnej znajomości prawd wiary, związku emocjonalnego z religią, poziomu praktyk religijnych, poziomu związku życia moralnego z religią oraz intensywności osobistego związku z Kościołem (Jaworski 1989, s. 85).

- Preferencje psychologiczne. Teoria typów psychologicznych Junga bazuje na modelu przeciwieństw tworzących pary czterech orientacji. Zgodnie $\mathrm{z}$ tą teorią, osoby wykazują preferencje w zakresie introwersji (I) lub ekstrawersji (E), zmysłowości (S) lub intuicji (N), myślenia (T) lub uczucia (F) oraz sądzenia (J) lub perceptywności (P). Wymiary te tworzą łącznie 16 wyraźnych typów psychologicznych, z których każdy jest oznaczany przez cztery początkowe litery preferencji (Francis 2005, s. 67-81).

- Obraz siebie (samoocena). Globalną samoocenę zwykle definiuje się jako wartościujący stosunek do własnej osoby. Samoocena jest podstawową zmienną dotyczącą postawy akceptacji bądź nieakceptacji siebie. Morris Rosenberg (1979) ujmuje samoocenę w kategorii postaw, skupiając się na rozwojowej perespektywie wpływu społecznych doświadczeń w kształowaniu się samooceny, oraz podkreślał znaczenie wartości jako kryterium samooceny. Rosenberg wyszczególnia trzy obszary obrazu siebie: (1) istniejące ,ja”(obrazy tego, jak się realnie prezentujemy); (2) ,ja" pożądane (idealne); (3) ,ja” obecnie ujawniane (wrażenie, jakie chcemy wywierać na innych). Samoocena (self-esteem) jest rozumiana jako motywacyjny komponent obrazu siebie (self-concept). Największym zagrożeniem dla samooceny jest samopotępianie, które jest naruszeniem wartości ,ja” moralnego (komponentu ,ja” pożądanego) (por. Fisher 1992, s. 18).

- Pięcioczynnikowy model osobowości. Czynniki modelu stanowią ponadkulturowe i ponaddemograficzne oraz strukturalnie najbardziej ogólne wymiary, pozwalające na pełną i wszechstronną charakterystykę osobowości (por. Costa 1992, s. 343-359; Zawadzki i in. 2007): Ekstrawersja (vs introwersja) - odnosi się do jakości i ilości interakcji społecznych, do poziomu aktywności, energii oraz zdolności doświadczania pozytywnych emocji; Ugodowość (vs antagonizm) - opisuje 
nastawienie do innych ludzi (pozytywne vs negatywne) przejawiające się w altruizmie vs antagonizmie; Sumienność (vs nieukierunkowanie) - oddaje stopień zorganizowania, wytrwałości i motywacji jednostki w działaniach zorientowanych na cel; Stałość emocjonalna (vs neurotyczność) - odzwierciedla przystosowanie emocjonalne vs emocjonalne niezrównoważenie i skłonność do przeżywania negatywnych emocji (strachu, zmieszania, gniewu, poczucia winy) oraz podatność na stres psychologiczny; Otwartość na doświadczenie - wskazuje na tendencję do pozytywnego wartościowania doświadczeń życiowych, tolerancję na nowość i ciekawość poznawczą (por. Sorokowska i in. 2014).

\section{Metody badań}

a) Skala Spójności Przekonań Religijnych (SSPR) Chaima (1991) służy do badania postawy wobec systemu doktrynalnego Kościoła katolickiego. Metoda uwzględnia trzy wymiary: Przekonania Podstawowe (PP) < 30 tw. >, Przekonania Kościelne (PK) < 10 tw. >, Przekonania Naturalne $(\mathrm{PN})<5$ tw. $>$. Jest narzędziem o sprawdzonej i odpowiedniej wartości psychometrycznej (rzetelność - metoda test-retest: $0,63<\mathrm{r}<0,88$; trafność treściowa oceniona przez kompetentnych sędziów; jednorodność testu mierzona współczynnikiem korelacji: $0,37<\mathrm{r}<0,82)$.

b) Skala Przekonań Post-krytycznych (Post-Critical BeliefScale-PCBS). Metoda skonstruowana przez Hutsebauta (1991) i współpracowników (Fontaine i in. 2003) do pomiaru czterech postaw religijnych wyróżnionych przez Wulffa. PCBS składa się z czterech podskal: krytyka zewnętrzna (literalne zaprzeczanie) - 9 tw., relatywizm (symboliczne zaprzeczanie) -8 tw., wtórna naiwność (symboliczna afirmacja) -8 tw., ortodoksja -8 tw. Rzetelność mierzona współczynnikiem a-Cronbacha wynosi dla skali ortodoksji a $=0,71$, krytyki zewnętrznej a $=0,87$, relatywizmu a $=0,72$ i wtórnej naiwności $\mathrm{a}=0,69$. Autorami polskiej adaptacji metody są: Bartczuk, Wiechetek i Zarzycka (2011).

c) Skala Samooceny Religijnej (SSR) autorstwa Jaworskiego (1989) obejmuje pięć pozycji, z odpowiedzią na skali Likerta (1-5) na każdą z nich. Obejmują one kolejno: ocenę własnej znajomości prawd religijnych, związku emocjonalnego z religią, poziomu praktyk religijnych, związku życia moralnego z religią oraz siły osobistego związku z religią.

d) Doświadczenie religijnego nawrócenia mierzone jest pytaniem o stopień przeświadczenia o przeżyciu tego rodzaju „nagłego” kontaktu 
z Bogiem. Badani posługiwali się skalą odpowiedzi typu Likerta: od „zdecydowanie tak” (5) do „zdecydowanie nie” (1).

e) Częstotliwość korzystania z Biblii; odpowiedź na pytanie o częstoliwość czytania Biblii była mierzona na skali od ,prawie nigdy” (1) do „częściej niż raz w tygodniu” (5). Stosunek do Biblii badano również metodą badania recepcji fragmentu Biblii (Mk 9,14-29), pytając o możliwości wyobrażenia siebie w odczytywanym opowiadaniu, identyfikację z konkretną postacią, związek uczuciowy z postaciami opowiadania oraz przez sprawdzenie, w jakiej perspektywie badani postrzegają tekst: współczesnej czy historycznej? Badani zakreślają na skali od 1 do 5 odpowiedzi na 11 twierdzeń sprawdzających jego rozumienie. Współczynnik rzetelności (aCronbacha) dla skali $(\mathrm{N}=86)$ wynosi 0,70 . Niski wynik wynik ogólny oznacza wybór perspektwy współczesnej, a wynik wysoki - wybór perspektywy historycznej w jego interpretacji.

f) Skala Samooceny (SES) Rosenberga - jest często stosowaną metodą pomiaru ogólnej samooceny, za pomocą 10 pozcji, które stanowią pomiar ogólnego poczucia własnej wartości i zadowolenia z siebie u osoby badanej. Podskala samooceny kompetencji mierzy skuteczność jednostki (poczucie bycia godnym zaufania, sprawnym, skutecznym), a podskala lubienia siebie mierzy poczucie własnej wartości (uczucie, że jestem dobry i społecznie cenny) (por. Schmitt i Allik 2005, s. 623-642). Każda pozycja jest oceniana na czterostopniowej skali Likerta, od 1 (,zdecydowanie się nie zgadzam”) do 4 (,zdecydowanie się zgadzam"). Pozycje nr 2, 5, 6, 8 i 9 są punktowane odwrotnie. Wysokie wyniki w SES wskazują na wysoką samoocenę. Wynik ogólny mierzy globalną samoocenę badanej osoby (por. Laguna i in. 2007). Badania prowadzone na różnych grupach wykazały, że polska wersja metody jest narzędziem rzetelnym (aCronbacha $=0,81-0,83)$, o potwierdzonej trafności teoretycznej (Laguna i in. 2007).

g) Skale Typu Psychologicznego Francisa (Francis Psychological Type Scales - FPTS) do pomiaru preferencji i typówy psychologicznych. FPTS oferuje cztery skale, liczące po 10 pozycji, w celu rozróżnienia preferencji między introwersją i ekstrawersją, zmysłowością i intuicją, uczuciem i myśleniem oraz sądzeniem i perceptywnością. Każda pozycja przedstawia wymuszony wybór między parami przeciwstawnych opisów (cech). Współczynniki aCronbacha wersji angielskiej wynoszą dla cztrech wymiarów: EI (0.83), SN (0.76), TF (0.73), JP (0.79) (Francis i in. 2008, s. 181-191). Tłumaczenia i adaptacji dokonał autor. Współczynniki aCronbacha $(\mathrm{N}=53)$ zastosowanej wersji były następujące: EI (0.71), SN (0.41), TF (0.77), JP (0.80). 
h) Krótki inwentarz osobowości (Ten Item Personality Inventory TIPI-PL). Kwestionariusz pozwala u badanej osoby zdiagnozować za pomocą 10 pytań wartości dla każdej z pięciu cech: ekstrawersja, ugodowość, sumienność, stabilność, otwartość na doświadczenie. Każdy z tych wymiarów tworzą dwie pozycje. Osoba badana jest proszona o ustosunkowanie się do każdego stwierdzenia na siedmiostopniowej skali Likerta, od 1 (,zdecydowanie się nie zgadzam”) do 7 (,zdecydowanie się zgadzam"). Badania wykazały satysfakcjonującą rzetelność skali TIPI-PL. Wartości współczynników aCronbacha pokazały, że skale TIPI-PL charakteryzują się zbliżoną lub wyższą rzetelnością w stosunku do skal wersji oryginalnej (por. Sorokowska i in. 2014).

\section{Charakterystyka badanych osób}

Przebadano 119 (w części testów 116) osób (43\% M, 57\% K) (n.i.), studentów uczelni wyższych: Lublina, Rzeszowa i Zamościa. Profil psychologiczny badanej młodzieży $(\mathrm{N}=119)$ zawiera wszystkie kompletne typy, przy czym typami najczęstszymi okazały się: ISTJ (16\%), ESFJ (13\%), ISFJ (12\%) oraz INFJ, INFP i ESFP (po 8\%). Wśród kobiet najczęściej występują: ESFJ $(17,4 \%)$, ISFJ $(11,6 \%)$, INFJ $(11,6 \%)$ oraz ISTJ $(10,1 \%)$; nie ma natomiast przedstawicielek typów: ISTP oraz ISFP. Wśród mężczyzn najczęstszymi typami były: ISTJ (24\%), ESTJ (14\%), ISFJ (12\%), nieobecne są natomiast typy: INTP, ENFP oraz ENTJ.

U studentów ujawnił się następujący rozkład preferencji psychologicznych: równowaga ekstrawersji (50\%) i introwersji (50\%), przewaga zmysłowości (63\%) nad intuicją (37\%), uczucia (59\%) nad myśleniem (41\%) oraz sądzenia (69\%) nad perceptywnością (31\%).

\section{Prezentacja wyników}

1. Grupy osób różniących się stosunkiem do treści religijnego nauczania i ustalenie zależności oraz korelacji między zmiennymi

Dane uzyskane metodą SSPR $(\mathrm{N}=121)$ poddano analizie czynnikowej (rotacja skośna, metodą Oblimin), z zadaną liczbą trzech czynników, w wyniku której potwierdziła się przynależność twierdzeń do pierwotnie zidentyfikowanych wymiarów (por. Chaim 1991 b, s. 3-14). Wysokość ładunków czynnikowych twierdzeń tworzących poszczególne wymiary wynosiła: Przekonania Podstawowe (0,31-0,84), Przekonania Kościelne (0,37-0,82); 
Przekonania Naturalne (0,38-0,56) (por. Chaim 1991 a). Analiza czynników potwierdza, że podstawą ich wyodrębnienia jest trojaki rodzaj asercji doktryny chrześcijańskiej: podmiotowe doświadczenie, autorytet eklezjalny, racjonalność („myślenie metafizyczne”).

$\mathrm{Na}$ kolejnym etapie celem ustalenia grup respondentów różniących się wynikami uzyskanymi w trzech wymiarach testu SSPR zastosowano metodę analizy skupień. Zastosowana niehierarchiczna budowa skupień obserwacji wokół medoid $\mathrm{z}$ automatycznym doborem liczby klastrów z wykorzystaniem testu istotności „Silhuette” wyodrębniła dwie grupy o średnich wynikach: I gr. $\mathrm{PP}=6,22, \mathrm{PK}=5,20, \mathrm{PN}=5,93$; II gr. $\mathrm{PP}=4,62, \mathrm{PK}=3,52$, $\mathrm{PN}=4,78$. Grupy było liczbowo podobne: I gr. $\mathrm{N}=53$, II gr. $\mathrm{N}=63$ i różniły się od siebie na poziomie bardzo istotnym ${ }^{2}$. Wyodrębnione grupy nie różniły się istotnie: wiekiem, stanem cywilnym, pochodzeniem społecznym, kierunkiem studiów, narodowością, ani wyznaniem.

Alternatywnie uzyskano grupy zróżnicowane w zakresie PP-PK-PN, zakładając z góry liczbę czterech skupień, stosownie do typologii niespójności przekonań (por. Chaim 1991 a). Grupy były liczbowo zbliżone: I gr. $\mathrm{N}=32$, II gr. $N=31$, III gr. $N=32$, IV gr. $N=22$. Średnie wyniki dla wyodrębnionych czterech skupień były następujące: I gr. $\mathrm{PP}=6,42, \mathrm{PK}=5,61, \mathrm{PN}=6,18$; II gr. $\mathrm{PP}=5,44, \mathrm{PK}=3,91, \mathrm{PN}=5.88$; III gr. $\mathrm{PP}=5,38, \mathrm{PK}=4,34, \mathrm{PN}=4,52$; IV gr. $\mathrm{PP}=3,69, \mathrm{PK}=2,87, \mathrm{PN}=4,39$. Wszystkie grupy między sobą różniły się na poziomie bardzo istotnym $(\mathrm{p}<0,0001)$.

Do dalszych analiz wybrano wersję dwu skupień, aczkolwiek podobny poziom istotnych różnic wystąpił także między czterema grupami. W celu stwierdzenia istotności różnic $\mathrm{w}$ zakresie zmiennych objaśniających między grupą I i II zastosowano test Kruskalla-Wallisa.

W tabeli 1 przedstawiono wyniki testu Kruskalla-Wallisa zastosowanego w celu sprawdzenia istotności różnic median (średnich) między grupami o zróżnicowanym stopniu akceptacji treści wiary.

W teście stylów religijnego myślenia (PCBS) między dwoma grupami różnice wystąpiły w trzech skalach: ortodoksji, wtórnej naiwności oraz krytyki zewnętrznej, na poziomie istotności wyższym niż 0,00001 . Porównywane grupy różnią się bardzo istotnie także w zakresie samooceny religijnej we wszystkich jej aspektach na poziomie $\mathrm{p}<0,0001$ : znajomość doktryny, związek emocjonalny z religią, poziom praktyk religijnych, związek życia moralnego z religią, osobisty związek z religią. W zakresie częstotliwości korzystania z Biblii różnica istotna wystąpiła na poziomie 0,01 . Grupy nie różnią się natomiast doświadczeniem nawrócenia. W wynikach TIPI-10 stwierdzono

${ }^{2}$ Wielowymiarowy test istotności różnic median/średnich między grupami Manna-Whitneya $(\mathrm{U}=84,44, \mathrm{p}<0,0001)$. 
istotną różnicę $\mathrm{w}$ ugodowości na poziomie 0,05 . W zakresie zmiennych testu FPTS (E-I, SS-N, T-F, J-P) między porównywami grupami nie stwierdzono istotnych różnic ${ }^{3}$.

Tabela 1. Istotność różnic między porównywanymi grupami

\begin{tabular}{|l|c|c|}
\hline \multicolumn{3}{|c|}{ Porównanie grup I i II zróżnicowanych w zakresie wymiarów SSPR (PP, PK, PN) } \\
\hline \multicolumn{1}{|c|}{ Zmienne } & Statystyka & Wartość $\mathrm{p}$ \\
\hline PCBS - Ortodoksja & 22,211 & 0,0001 \\
\hline PCBS - Wtórna naiwność & 44,926 & 0,0001 \\
\hline PCBS - Relatywność & 1,369 & n.i. \\
\hline PCBS - Krytyka zewnętrzna & 29,851 & 0,0001 \\
\hline SSR - Wynik ogólny & 42,755 & 0,0001 \\
\hline SSR - Znajomość prawd religijnych & 16,413 & 0,0001 \\
\hline SSR - Zwiqzek emocjonalny z religia & 44,293 & 0,0001 \\
\hline SSR - Poziom praktyk religijnych & 28,069 & 0,0001 \\
\hline SSR - Powiqzanie moralności z religia & 21,845 & 0.0001 \\
\hline SSR - Osobisty zwiqzek z religiq & 31,640 & 0.0001 \\
\hline Biblia - częstotliwość lektury & 6,202 & 0,01 \\
\hline Doświadczone nawrócenie & 2,676 & n.i. \\
\hline SES - Samoocena (obraz siebie) & 4,371 & 0,05 \\
\hline TIPI - 10 Ekstrawersja. & 3,039 & n.i. \\
\hline TIPI - 10 Ugodowość & 4,005 & 0,05 \\
\hline TIPI - 10 Sumienność & 2,425 & n.i. \\
\hline TIPI - 10 Stabilność & 0,825 & n.i. \\
\hline TIPI - 10 Otwartośćc & 0,475 & n.i. \\
\hline
\end{tabular}

W celu szczegółowego porówniania różnic międzygrupowych na drugim etapie (każdy z każdym) zastosowano test U-Manna-Whitneya. W tabeli 2 przedstawiono istotności różnic pomiędzy wymiarami w poszczególnych grupach wykonane za pomocą testu Kruskala-Wallisa oraz Dunna (z uwagi na nierówną liczebność grup) z odpowiednią korektą.

${ }^{3}$ Istotna różnica $\mathrm{w}$ korzystaniu z Biblii $(\mathrm{p}<0,05)$ wystąpiła przy porównaniu czterech grup. W porównaniu czterech grup miały miejsce różnice także w teście FPTS w wymiarze sądzenie - perceptywność (J-P) na poziomie $\mathrm{p}<0,01$ oraz $\mathrm{w}$ teście TIPI-10 w ekstrawersji na poziomie $\mathrm{p}<0,05$. 
Tabela 2. Istotności różnic pomiędzy zmiennymi porównywanych grup ${ }^{4}$

\begin{tabular}{|l|c|c|c|c|c|c|}
\hline \multicolumn{1}{|c|}{ ZMIENNE } & M gr. I & M gr. II & Me gr.I & Me gr. II & p dla M & p dla Me \\
\hline PCBS - Ortodoksja & 4,32 & 3,65 & 4,4 & 3,6 & 0,0001 & 0,0001 \\
\hline PCBS - Wtórna naiwność & 5,68 & 4,53 & 5,7 & 4,5 & 0,0001 & 0,0001 \\
\hline PCBS - Relatywność & 4,16 & 4,35 & 4,2 & 4,4 & n.i. & n.i. \\
\hline PCBS - Krytyka zewnętrzna & 2,99 & 3,98 & 3,0 & 4,0 & 0,0001 & 0,0001 \\
\hline SSR - Samoocena religijna & 3,65 & 2,69 & 3,6 & 2,8 & 0,0001 & 0,0001 \\
\hline E-I & 0,45 & 0,55 & 0,0 & 1,0 & n.i. & n.i. \\
\hline S-N & 0,58 & 0,67 & 1,0 & 1,0 & n.i. & n.i. \\
\hline T-F & 0,32 & 0,46 & 0,0 & 0,0 & n.i. & n.i. \\
\hline J-P & 0,74 & 0,63 & 1,0 & 1,0 & n.i. & n.i. \\
\hline Ekstrawersja & 5,47 & 4,84 & 5,5 & 4,5 & 0,05 & n.i. \\
\hline Ugodowość & 5,39 & 4,79 & 5,5 & 5,0 & 0,05 & 0,05 \\
\hline Sumienność & 5,49 & 5,11 & 5,5 & 5,0 & n.i. & n.i. \\
\hline Stabilność & 4,05 & 3,78 & 4,0 & 4,0 & n.i. & n.i. \\
\hline Otwartość & 4,52 & 4,68 & 4,5 & 4,5 & n.i. & n.i. \\
\hline Skala samooceny (SES) & 2,48 & 2,31 & 2,5 & 2,4 & 0,05 & 0,05 \\
\hline
\end{tabular}

Uzupełniających informacji na temat powiązania między badanymi zmiennymi dostarczają współczynniki korelacji między nimi. W tabeli 3 zawarto korelacje między zmiennymi przekonań religijnych a zmiennymi religijności (style myślenia, samoocena religijna, nawrócenie, ubiblijnienie) i osobowości (preferencje psychologiczne, cechy osobowości, obraz siebie).

Tabela 3. Współczynniki korelacji (r-Pearsona, ro-Spearmana) między badanymi zmiennymi

\begin{tabular}{|l|c|c|c|}
\hline \multicolumn{1}{|c|}{ Zmienne religijności } & SSPR-PP & $S S P R-P K$ & $S S P R-P N$ \\
\hline PCBS - Ortodoksja & $0,55^{* * * *}$ & $0,61 * * * *$ & $0,21^{*}$ \\
\hline PCBS - Wtórna naiwność & $0,69 * * * *$ & $0,64 * * * *$ & $0,51 * * * *$ \\
\hline PCBS - Relatywność & $-0,12$ & $-0,17$ & $-0,12$ \\
\hline PCBS - Krytyka zewnętrzna & $-0,56 * * * *$ & $-0,47 * * * *$ & $-0,53 * * * *$ \\
\hline Samoocena religijności (SSR) & $0,63 * * * *$ & $0,66 * * * *$ & $0,46 * * * *$ \\
\hline
\end{tabular}

${ }^{4}$ Dla porównania zastosowano dwa testy: do porównania średnich - k-sample t-test; do porównania median - Kruskal-Wallis test. 


\begin{tabular}{|l|c|c|c|}
\hline \multicolumn{1}{|c|}{ Zmienne religijności } & SSPR-PP & SSPR-PK & SSPR-PN \\
\hline Doświadczenie nawrócenia & $0,24^{* *}$ & $0,31^{* * *}$ & $0,27^{* *}$ \\
\hline Biblia - częstotliwość korzystania & $0,27^{* *}$ & 0,17 & $0,33^{* * * *}$ \\
\hline Scena z Biblii - możliwość wyobrażenia siebie & $-0,27^{* *}$ & $-0,18$ & $-0,30^{* *}$ \\
\hline Identyfikacja z konkretną postacią & $-0,16$ & $-0,07$ & $-0,10$ \\
\hline Siła identyfikacji z bohaterami sceny biblijnej & $0,30^{* *}$ & $0,21^{*}$ & 0,18 \\
\hline Perspektywa recepcji tekstu (współczesna vs historyczna) & $-0,29^{* *}$ & $-0,21^{*}$ & $-0,29^{* *}$ \\
\hline Zmienne osobowości & & & \\
\hline Ekstrawersja - Introwersja (E-I) & $-0,13$ & $-0,05$ & $-0,16$ \\
\hline Zmysłowość - Intuicja (S-N) & $-0,19 *$ & $-0,17$ & $-0,06$ \\
\hline Myślenie - Uczucie (T-F) & $-0,22^{*}$ & $-0,19 *$ & 0,17 \\
\hline Sądzenie - Perceptywność (J-P) & 0,04 & 0,00 & 0,01 \\
\hline TIPI - 10 Ekstrawersja & 0,16 & $0,21^{*}$ & 0,03 \\
\hline TIPI - 10 Ugodowość & $0,22^{*}$ & $0,21^{*}$ & $0,23 *$ \\
\hline TIPI - 10 Sumienność & 0,13 & 0,12 & 0,00 \\
\hline TIPI - 10 Stabilność & 0,06 & 0,14 & 0,13 \\
\hline TIPI - 10 Otwartość & 0,08 & $-0,09$ & 0,04 \\
\hline Samoocena - obraz siebie (RSES) & 0,18 & $0,27 * *$ & $-0,03$ \\
\hline
\end{tabular}

Korelacja na poziomie: $* \mathrm{p}<0,05 ; * * \mathrm{p}<0,01 ; * * * \mathrm{p}<0,001 ; * * * * \mathrm{p}<0,0001$.

\section{Weryfikacja hipotez}

Stwierdzono istotne różnice w poziomie zmiennych religijności w porównywanych grupach o zróżnicowanym stosunku do chrześcijańskiej doktryny religijnej:

H 1a: Stwierdzono powiązanie między stopniem akceptacji przekonań religijnych a stylami myślenia religijnego: ortodoksją, wtórną naiwnością i krytyką zewnętrzną na poziomie 0,0001 . Osoby z obniżoną intensywnością przekonań religijnych ujawniają niższy poziom ortodoksji, wtórnej naiwności, a jednocześnie wyższy poziom krytyki zewnętrznej.

H 1b: Stwierdzono powiązanie między stopniem akceptacji przekonań religijnych a zmiennymi religijności. Osoby z wyższym poziomem asercji przekonań religijnych wykazują się wyższą samooceną religijną w jej wszystkich wymiarach (wiedza religijna, przywiązanie emo- 
cjonalne do religii, zaangażowanie $\mathrm{w}$ religijne praktyki, powiązanie moralności z religią, osobisty związek z religią) na poziomie 0,0001 . W dwóch porównywanych grupach nie potwierdziło się założenie, że osoby o intensywniejszych przekonaniach religijnych doświadczały więcej przeżycia Sacrum (doświadczenie religijne). Zależność taką stwierdzono jednak w wersji porównania między czterema gupami na poziomie 0,01 . Osoby, które intensywniej akceptują treści wiary, częściej mają kontakt z Biblią (różnica na poziomie $0,01 \mathrm{w}$ wersji dwóch grup, natomiast $\mathrm{w}$ wersji czterech grup na poziomie 0,001 ).

Zasadniczo nie stwierdzono różnic w poziomie zmiennych osobowości w grupach o zróżnicowanycm stosunku do doktryny religijnej:

H 2a: W teście wymiarów typów psychologicznych (E-I, S-N T-F, J-P) nie stwierdzono różnic między dwoma porównywanymi grupami; w wersji czterech grup wystąpiła jednak istotna różnica na poziomie 0,05 w wymiarze myślenie - uczucie.

H 2b: Porównywane grupy w zakresie ogólnej samooceny mierzonej SES Rosenberga różnią się istotnie na poziomie 0,05 , także w wersji czterech grup; osoby intensywniej akceptujące treści doktrynalne przejawiają wyższy poziom samoakceptacji.

H 2c: Grupy porównywane w zakresie wymiarów Wielkiej Piątki (TIPI-10) różnią się istotnie $(\mathrm{p}<0,05)$ jedynie w zakresie ekstrawersji oraz ugodowości; intensywniej akceptujący treści doktrynalne przejawiają wyższy poziom ekstrawersji i ugodowości.

Pełniejszemu wglądowi w stwierdzone zależności może posłużyć tablica korelacji między badanymi zmiennymi. $Z$ wymiarem przekonań podstawowych (PP) wysoko dodatnio korelują style myślenia religijnego (PCBS): wtórna naiwność $(0,70)$ i ortodoksja $(0,55)$ oraz samoocena religijna $(0,63)$ przy jednoczesnej ujemnej korelacji z krytyką zewnętrzną $(-0,57)$. Z wymiarem przekonań kościelnych (PK) podobnie wysoko dodatnio korelują style myślenia: wtórna naiwność $(0,64)$ i ortodoksja $(0,61)$ oraz samoocena religijna $(0,68)$ przy jednoczesnej ujemniej korelacji z krytyką zewnętrzną $(-0,49)$ i relatywnością $(-0,21)$. Z wymiarem przekonań naturalnych, z kolei, koreluje dodatnio wtórna naiwność $(0,51)$ i ortodoksja $(0,22)$ oraz samoocena religijna $(0,43)$ przy jednoczesnej wysokiej korelacji ujemnej z krytyką zewnętrzną $(-0,52)$. Łatwo zauważyć, że spośród stylów religijnego myślenia z przekonaniami podstawowymi najwyżej dodatnio koreluje wtórna naiwność (symboliczna interpretacja treści credo). Wtórna naiwność bardzo wysoko koreluje także z asercją przekonań kościelnych i przekonań naturalnych. Ortodoksja 
(dosłowna interpretacja treści wiary) koreluje najwyżej z wymiarem przekonań kościelnych, a najmniej z wymiarem przekonań naturalnych. W nieco słabszym nasileniu krytyka zewnętrzna (literalne rozumienie treści wiary oraz odrzucanie ich) koreluje ujemnie ze wszystkimi wymiarami przekonań religijnych. Ta korelacja jest wyższa z PP i PN prawdopodobnie z racji deficytu czynników - źródeł asercji: doświadczenia wiary i „myślenia metafizycznego”. Samoocena religijna istotnie i wysoko koreluje $\mathrm{z}$ akceptacją treści wiary, a najmniejszą współzależność przejawia z przekonaniami naturalnymi.

$\mathrm{Z}$ kolejnych zmiennych religijności, doświadczenie religijne koreluje dodatnio w umiarkowanym stopniu ze wszystkimi wymiarami SSPR. Częstotliwość posługiwania się Biblią koreluje dodatnio na podobnym poziomie z PN i PP, lecz niestety nie koreluje z PK, co może świadczyć, że bezpośredni kontakt z Biblią (prawdopodobnie z powodu rzadkiego korzystania i braku rozumienia) $\mathrm{w}$ niewielkim stopniu wzmacnia asercję eklezjalnych treści wiary. Zaufanie do swojej wyobraźni w odbiorze tekstu biblijnego ujemnie koreluje z akceptacją PP i PN. Zdolność do identyfikacji z postaciami tektu biblijnego koreluje dodatnio w pewnym stopniu z akceptacją PP i PK, lecz nie z PN. Stosowana perspektywa (współczesna) w recepcji tekstu biblijnego w podobnym stopniu koreluje z PP, PN i PP.

$\mathrm{Z}$ akceptacją treści przekonań dwa wymiary osobowości mierzone FPTS w niewielkim stopniu korelują ujemnie na poziomie istotnym: z PP koreluje myślenie - uczucie oraz zmysłowość - intuicja, z PK koreluje wymiar myślenie - uczucie. Typy zmysłowe i uczuciowe korelują dodatnio z asercją przekonań chrześcijańskich (podstawowych i kościelnych). Wymiar J-P nie jest skorelowany $\mathrm{z}$ akceptacją treści wiary, odwrotnie niż $\mathrm{w}$ podobnym studium w relacji do chrześcijaństwa (por. Francis i in. 2004, s. 15-34). Spośród cech osobowości mierzonych metodą TIPI-10 cecha ugodowości koreluje dodatnio ze wszystkimi wymiarami przekonań religijnych; z przekonaniami kościelnymi $(0,24)$, przekonaniami podstawowymi $(0,20)$ i przekonaniami kościelnymi $(0,18)$. W mniejszym stopniu, dodatnią korelację stwierdzono między cechą ekstrawersji a przekonaniami kościelnymi $(0,21)$ i podstawowymi $(0,15)$. Obraz siebie (SES) jest pozytywnie skorelowany jedynie z wymiarem przekonań kościelnych $(0,23)$.

\section{Konkluzje}

Efektem przeprowadzonych badań jest stwierdzenie powiązań stylów pomiędzy stylami myślenia religijnego oraz samooceny religijności z intensywnością akceptacji chrześcijańskiego credo. Z bardziej intensywną akceptacją treści wiary wiąże się, prawdopodobnie wywierając pozytywny wpływ, 
poszukiwanie głębokiego rozumienia ich sensu. Co więcej, wtórna naiwność bardzo mocno powiązana jest także $\mathrm{z}$ akceptacją twierdzeń eklezjalnych oraz naturalnych. Ocena własnej religijności z podobnym nasileniem koreluje ze wszystkimi wymiarami religijnej doktryny ${ }^{5}$. W intensywność akceptacji credo w podobnym stopniu włączona jest interpretacja dosłowna, tzn, że te dwie interpretacje nie wykluczają się. Osoby, które pełniej oraz intensywniej akceptują treści swojej wiary, w większym stopniu stosują interpretację symboliczną niż osoby podchodzące do credo z mniejszym przekonaniem i bardziej wybiórczo. Natomiast osoby z obniżoną intensywnością i wybiórczym stosunkiem do treści wiary częściej stosują literalną ich interpretację. Takie odrzucanie dosłownie interpretowanych twierdzeń religijnych (krytyka zewnętrzna) może łączyć się ze szywnością poznawczą, co utrudnia przyjmowanie chrześcijańskiego nauczania we wszystkich trzech zakresach: podstawowych, kościelnych i naturalnych. Z akceptacją treści wiary wszystkich trzech wymiarów koreluje dodatnio także doświadczenie nawrócenia. Jest znamienne, że częstotliwość kontaktu z Biblią nie koreluje z przekonaniami kościelnymi, czyli że są one słabo ,ubiblijnione”. Akceptacji treści wiary we wszytkich trzech aspektach towarzyszy współczesna perspektywa w interpretacji tekstu biblijnego. Czy nie jest to spowodowane niewielkim poziomem wiedzy nt. Biblii? Stosunek do występujących postaci nie koresponduje z asercją przekonań religijnych. Co więcej, możliwość wyobrażenia siebie w podanej narracji biblijnej negatywnie koreluje z intensywnością przekonań zarówno podstawowych, jak i naturalnych.

W obszarze związków między asercją przekonań religijnych a zmiennymi osobowości stwierdzono jedynie nieliczne współzależności. Osoby o zróżnicowanym stosunku do treści wiary różnią się poziomem samooceny; u osób intensywniej akceptującyh credo ten poziom jest wyższy. Z przedstawionych korelacji wynika, że wpływ na to może mieć akceptacja treści eklezjalnych związana z identyfikacją z Kościołem. Stwierdzono zależność między asercją przekonań religijnych a cechami ekstrawersji i ugodowości. Warto zauważyć, że zarówno niektóre cechy osobowości (TIPI-10), jak i funkcje psychologiczne (FPTS) korelują istotnie z wymiarami przekonań. Akceptacja przekonań podstawowych wiąże się z przewagą zmysłowości nad intuicją oraz myślenia nad uczuciem. Także akceptacja twierdzeń eklezjalnych wiąże się z preferencją myślenia nad uczuciem. Z kolei, ugodowość koreluje dodatnio ze wszyst-

\footnotetext{
${ }^{5}$ Warto dodać, że samoocena religijna (SSR) koreluje dodatnio ze stylami religijnego myślenia (PCBS): ortodoksją $(0,54 ; \mathrm{p}<0,001)$, wtórną naiwnością $(0,61 ; \mathrm{p}<0,0001)$, a ujemnie z relatywnością $(-0,22 ; p<0,05)$ i krytyką zewnętrzną $(0,50 ; p<0,001)$ w teście PCBS. Koreluje dotatnio także z nawróceniem $(0,29 ; \mathrm{p}<0,01)$, korzystaniem z Biblii $(0,37 ; \mathrm{p}<0,001)$, identyfikacją z konkretną postacią $(0,34 ; \mathrm{p}<0,001)$, ujemnie z możliwością wyobrażenia siebie w roli z tekstu $(-0,21$; $\mathrm{p}<0,05)$ oraz $\mathrm{z}$ wyborem perspektywy współczesnej w interpretacji tekstu $(-0,28 ; \mathrm{p}<0,01)$.
} 
kimi wymiarami przekonan, a ekstrawersja koreluje dodatnio $\mathrm{z}$ akceptacją twierdzeń kościelnych. Te wyniki w pewnym stopniu potwierdzają niektóre wyniki na ten temat przytoczone w części teoretycznej artykułu.

Do braków tych badań należy zaliczyć niedoskonałość metod do badania osobowości (FPTS, TIPI-10-PL). Inną kwestią do uwzględnienia w przyszłych badaniach jest zwiększenie próbki badawczej. Jednym z efektów ubocznych uzyskanych wyników jest informacja nt. trafności zewnętrznej metody SSPR, na co wskazują wysokie korelacje wymiarów testu z wymiarami SSR i wymiarami PCBS (ortodoksja i wtórna naiwność - pozytywnie, a krytyka zewnętrzna - negatywnie) oraz źródłami ich asercji: doświadczenia z przedmiotem religijnym (osobowy Bóg), autorytet Kościoła oraz racjonalne poszukiwanie i odkrywanie sensu rzeczywistości.

\section{STRESZCZENIE}

Przedmiotem artykułu są teoretyczne i empiryczne relacje między postawą wobec doktryny religii chrześcijańskiej a innymi zmiennymi religijności oraz osobowością. Prównano dwie grupy osób istotnie zróżnicowanych stopniem akceptacji trzech wymiarów Skali Spójności Przekonań Religijnych (przekonania podstawowe, przekonania kościelne, przekonania naturalne) w zakresie kilku innych apektów religijności (religijne style poznawcze, samoocena religijności, nawrócenie, częstotliwość korzystania z Biblii i sposoby jej recepcji) oraz kilku aspektów osobowości (obraz siebie, preferencje psychologiczne, cechy osobowości).

Stwierdzono, że osoby zróżnicowane w zakresie postawy wobec chrześcijańskiego credo różnią się istotnie także w zakresie wymiarów - stylów religijnego myślenia (ortodoksja, wtórna naiwność, krytyka zewnętrzna): oceną swojej religijności, częstotliwością posługiwania się Biblią, obrazem siebie, ugodowością oraz ekstrawersją. Respondenci, którzy wykazywali wyższy stopień akceptacji trzech wymiarów doktryny chrześcijańskiej, uzyskali istotnie wyższe wyniki w dwóch wymiarach religijnego myślenia (ortodoksji i wtórnej naiwności), w religijnej samoocenie, dwóch cechach osobowości (ekstrawersji i ugodowości) oraz w obrazie siebie. Respondenci, którzy w akceptacji doktryny chrześcijańskiej uzyskali istotnie niższe wyniki, uzyskali istotnie wyższe wyniki w zakresie krytyki zewnętrznej.

W celu uzyskania lepszego wglądu w otrzymane rezultaty porównań, dodatkowo zostały przedstawione także współczynniki korelacji miedzy badanymi zmiennymi.

Słowa kluczowe: religijność; style myślenia religijnego; Skala Spójności Przekonań Religijnych; Wielka Piątka 


\section{THE LEVEL OF ACCEPTANCE \\ OF THE CHRISTIAN DOCTRINAL STATEMENTS, RELIGIOSITY AND PERSONALITY. EMPIRICAL RESEARCH ON STUDENTS}

\section{SUMMARY}

The article presents a theoretical and empirical relationship between a person's attitude toward the Christian doctrine and their religiosity as well as personality variables. Two groups which significantly differed in the level of acceptance of the Christian doctrine (Scale of Coherence of Religious Convictions) were compared in terms of several aspects of religiosity (measured using Post-Critical Beliefs Scale, Scale for Self-evaluation of Religiousness, and scales of acquaintance with the Bible) and several aspects of personality (measured using Rosenberg's Self-Esteem Scale, Francis Psychological Type Scales, and Ten Item Personality Inventory-PL). Both compared groups varied significantly with regard to Orthodoxy, Second Naivity, and External Critique (PCBS), self-evaluation of religiousness (SSR), contact frequency to the Bible, and self-esteem (RSES), as well as to Agreeableness (TIPI-PL). The respondents who more intensively asserted the three dimensions of Christian doctrine achieved significantly higher scores for the following variables: Orthodoxy, Second Naivity $(P C B S)$, self-evaluation of religiousness (SSR),Extraversion, Agreeableness (TIPI$P L)$ and self-esteem (RSES). Respondents with a lower level of assertion of the Christian doctrine achieved significantly higher scores for the External Critique $(P C B S)$. In order to gain more understanding of the achieved results correlation coefficients between the measured variables were calculated.

Keywords: religiosity; styles of religious thinking; Scale of Coherence of Religious Convictions; self-esteem; Big Five

\section{BIBLIOGRAFIA}

Abdel-Khalek A.M., Al-Jawhary S.W. (2017): Religiosity and its relation to the Big Five personality factors in Kuwaiti adolescents. http://www.jac-kw.org/ksaac/images/531.pdf [dostęp: 18.08.2017).

Agu S.A., Nwankwo B.E., Obi T.C., Aboh J.U., Anike R.U. (2013): Influence of religion on the development of self-concept in adolescents. „International Journal of Humanity and Social Sciences" 2: 2013 s. 46-48.

Bagley C., Mallick K. (1997): Self-esteem and religiosity: comparison of 13-15 year old students in Catholic and Public Junior High Schools. „Canadian Journal of Education” 22: 1997 (1) s. 89-92 .

Bartczuk R.P., Wiechetek M.P., Zarzycka B. (2011): Skala Przekonań Postkrytycznych D. Hutsebauta. W: M. Jarosz (red.), Psychologiczny pomiar religijności s. 201-229. Lublin.

Bhalla M., Cornwell J., Thames J.R. (2003): Relationship Among Adolescent Self-Esteem, Religiosity, and Perceived Family Support. „Psi Chi Journal of Undergraduate Research” 8: 2003 (4) s. $157-162$. 
Centrum Badania Opinni Publicznej [CBOS]. (2015). Zmiany w zakresie podstawowych wskaźników religijności Polaków po śmierci Jana Pawła II. https://www.cbos.pl/SPISKOM.POL/ 2015/K_026_15.PDF.

Chaim W. (2017): Koncepcja typów psychologicznych w psychologii religiii duchowości. „Roczniki Psychologiczne" 20: 2017 (1) s. 31-45.

Chaim W. (1991 a): Psychologiczna analiza religijności niespójnej. Lublin.

Chaim W. (1991 b): Religijność spójna. Pojęcie i pomiar. „Analecta Cracoviensia” 23: 1991 s. 3-14.

Costa P.T. (1992): The Five-Factor Model of Personality and Its Relevance to Personality Disorders. „Journal of Personality Disorders” 6: 1992 (4) s. 343-359.

Delis-Bulhoes (1990): Jungian psychological types and Christian belief in active church members. „Journal of Psychological Type” 20: 1990 s. 25-33.

Donahue M.J., Benson P.L. (1995): Religion and the well-being of adolescents. „Journal of Social Issues" 51: 1995 s. 145-160.

Duriez B., Soenens B., Beyers W. (2004): Personality, identity styles, and religiosity: an integrative study among late adolescents in Flanders (Belgium). ,Journal of Personality” 72: 2004 s. $877-$ -910 .

Duriez B., Soenens B. (2006): Personality, identity styles, and religiosity: an integrative study among late and middle adolescents. „Journal of Adolescence” 29: 2006 s. 119-135.

Engelsma D.J. (1990): Is good self-esteem important for a Christian, and how is it developed? Perspectives in Covenant Education 1990. http:/www.prca.org/resources/publications/pamphlets/ item/1569-is-good-self-esteem-important-for-a-christian-and-how-is-it-developed [dostęp: 28.06. 2018].

Fearn M., Francis L.J., Wilcox C. (2001): Attitude towards Christianity and psychological type: a survey among religious studies students. „Pastoral Psychology” 49: 2001 s. 341-348.

Fearn M., Lewis C.A., Francis L.J. (2003): Religionand personality among religious studies students: a replication. „Psychological Reports” 93: 2003 s. 819-822.

Fisher P.A. (1992): The relationship of the self-esteem variable to specific Christian doctrines. https:// digitalcommons.andrews.edu/cgi/viewcontent.cgi?article=1037\&context=theses [dostęp: 28.06. 2018].

Fontaine R.J., Duriez B., Luyten R., Hutsebaut D. (2003): The internat structureofthe Post-Critical BeliefScale. „Personality and Individual Differences” 35: 2003 s. 501-518.

Francis L.J. (2005): Faith and psychology. Personality, religion and the individual. London.

Francis L.J. (1992): Is psychoticism really a dimension of personality fundamental to religiosity? „Personality and Individual Differences”13: 1992 s. 645-652.

Francis L.J. (1991): Personality and attitude towards religion among adult churchgoers in England. „Psychological Reports” 69: 1991 s. 791-794.

Francis L.J., Craig C.L., Hall G., Psychological type and attitude toward Celtic Christianity among commited churchgoers in the United Kingdom: an empirical study, „Journal of Contemporary Religion" 23: 2008 s. 181-191.

Francis L.J., Jackson Ch.J. (2003): Eysenck's dimensional model of personality and religion: are religious people more neurotic? „Mental Health, Religion und Culture” 6: 2003 (1) s. 87-100.

Francis L.J., Jones S.H., Craig C.L. (2004): Personality and religion: the relationship between psychological type and attitude toward Christianity. ,Archiv für Religionspsychologie” 26: 2004 s. 15-34.

Francis L.J., Jones S.H., Personality and Christian belief among adult churchgoers, „Journal of Psychological Type" 47: 1998 s. 5-11.

Francis L.J., Pearson P.R., Carter M., Kay W.K. (1981): Are introverts more religious? „British Journal of Social Psychology" 20: 1981 s. 101-104.

Francis L.J., Robbins M., Boxer A., Lewis C.A., McGuckin C., McDaid C.J. (2003): Psychological type and attitude toward Christianity: a replication. „Psychological Report” 92: 2003 s. 89-90.

Gerhardt R. (1983): Liberal religion and personality type. „Research in Psychological Type” 6: 1983 s. 47-53. 
Hamm R.J. (1976): Alternate forms for global self-concept and an achievement-related subscale using the Brownfain self-rating inventory. „Psychological Report” 39: 1976 s. 1196-1198.

Hills P.R., Francis L.J., Jennings P. (2006): Religious behavior, personality, and dimensions of selfesteem among 13- to 15-year-old adolescents. „Journal of Research on Christian Education” 15: 2006 s. 61-76.

https://ohssocialscienceresearch.wordpress.com/2015/12/10/examining-the-relationship-betweenreligiosity-and-self-esteem-among-adolescents-by-zachary-koval-2/ [dostep:19.07.2018].

Hutsebaut D. (1996): Post-critical belief. A new approach to the religious attitude problem. „Journal of Empirical Theology" 9: 1996 s. 48-66.

Jak to jest $z$ ta wiara $w$ Polsce? https://wiadomosci.onet.pl/tylko-w-onecie/religijnosc-w-polscestatystyki-dotyczace-religii/r145gks [dostęp: 9.07.2018].

Jaworski R. (1989): Psychologiczne korelaty religijności personalnej. Lublin. 1989.

Jennings P. (2003): The impast of different approaches to religious education on spirituals and moral attitudes of year nine and year ten pupils. Adissertationin the University of Wales. http://e. bangor.ac.uk/4032/2/273638.pdf [dostęp: 28.06. 2018].

Jones S.H., Francis L.J. (1999): Personality type and attitude toward Christianity among student churchgoers. „Journal of Beliefs and Values” 20: 1999 s. 105-109.

Jones S.H., Francis L.J. (1996): Religiosity and self-esteem during childhood and adolescence. W: L.J. Francis, W.K. Kay, W.S. Campbell (red), Research in religious education s. 189-205. Leominster.

Khoynezhad G., Rajaei A.R., Sarvarazemy A. (2012): Basic religious beliefs and personality trait. „Iran Journal Psychiatry” 7: 2012 (2) s. 82-86.

Krauze N. (1995): Religiosity and self-esteem among older adults. „The Journals of Gerontology” 50B: 1995 (5) s. 236-246.

Laguna M., Lachowicz-Tabaczek K., Dzwonkowska I. (2007): Skala samooceny SES Morrisa Rosenberga. https://www.kul.pl/files/118/publikacje_artyk/Laguna_PS_2007_2.pdf [dostęp: 29.06.2018].

Lee S.W. (1986): The orthodoxy of Christian beliefs and Jungian personality type. „Dissertation Abstracts International" 47: 1986 s. 47-A.

Lewis Ch.A., Maltby J. (1995): Religiosity and personality among U.S. adults. „Personality and Individual Differences" 18: 1995 (2) s. 293-295.

Liu J.K. (2013): Idol worship, religiosity, and self-esteem among university and secondary students in Hong Kong. „Discovery - SS Student E-journal” 2: 2013 s. 15-28.

Maltby J. (1997): Personality correlates of religiosity among adults in the Republic of Ireland. „Psychological Reports" 81: 1997 (3) s. 827-831.

Martos T., Thege B.K., Steger M. F. (2010): It's not only what you hold, it's how you hold it: dimensions of religiosity and meaning in life. „Personality and Individual Differences” 49: 2010 (8) s. $863-868$.

Mather D.M. (2015): Faith in yourself: self-esteem in Guatemalan religious schools. „RISE -International Journal of Sociology of Education" 4: 2015 (1) s. 69-97.

McCullough M.E., Tsang J.A., Brion S. (2002): Personality traits in adolescence as predictors of religiousness in early adulthood: Findings from the Terman longitudinal study. http:// www.psy.miami.edu/faculty/mmccullough/Papers/Relig-Big\%20Five_2002_dr2.pdf [dostęp: 29.06.2018].

Meyer P.G. (1966): Factors related to adherence to denominational patterns among Missouri Synod Lutheran College students. „Dissertation Abstracts International” 27: 1966 s. 169-A.

Moore K., Stoner S. (1977): Adolescent self-reports and religiosity. „Psychological Reports” 41: 1977 s. 55-56.

Murphy P. (2009): An investigation into the relationship between religion, self-esteem, perceived stress and general health in a student sample. https://esource.dbs.ie/handle/10788/1483 [dostęp: 28.06.2018]. 
Pervin L.A., Oliver P.J. (2002): Osobowość. Teoria i badania. Kraków.

Prężyna W. (1981): Funkcja postawy religijnej w osobowości człowieka. Lublin.

Prężyna W. (1975): Obraz siebie a intensywność postawy religijnej. „Roczniki Filozoficzne” 23: 1975 (4) s. 21.

Radoń S. (2018): Dojrzalość religijna młodzieży przygotowującej się do bierzmowania a spójność przekonań. RadonSSCDjrzaloscreligijnaaspojnosc.docx, www.researchgate.net [dostęp: 16.07.2018].

Rosenberg M. (1979): Conceiving the Self. New York.

Ross C.F.J., Weiss D., Jackson L. (1996): The relation of Jungian psychological type to religious attitudes and practices. „The International Journal for the Psychology of Religion” 6: 1996 (4) s. 263-279.

Saroglou V. (2002): Religion and the five factors of personality: a meta-analytic review. „Personality and Individual Differences" 32: 2002 s. 15-25.

Schmitt D.P., Allik J. (2005): Simultaneous administration of the Rosenberg Self-Esteem Scale inin 53 nations: exploring the universal and culture-specific features of global self-esteem. „Journal of Personality and Social Psychology" 89: 2005 (4) s. 623-642.

Searles R. (2012): Religious people have higher self-esteem but only in some countries. http://www. huffingtonpost.com/2012/01/20/religion-happiness_n_1219295.html [dostęp: 28.06.2018].

Sedikides C., Gebauer J.E. (2013) Religion and the self. http://www.southampton.ac.uk/ crsi/Sedikides\%20_Gebauer\%202013.pdf [dostęp: 28.06.2018].

Smith Ch.B., Weigert A.J., Thomas D.L. (1979): Self-esteem and religiosity: an analysis of Catholic adolescents from five cultures. „Journal for the Scientific Study of Religion” 18: 1979 (1) s. 51-60.

Smither J.W., Walker A.G. (2015): The relationship between core self-evaluations, views of god, and intrinsiclextrinsic religious motivation. „Psychologocal Reports” 116: 2015 (2) s. 647-662.

Sontakke J. (2017): Personality and religiosity; a correlational study. „International Journal of Research in Humanities, Arts and Literature" 5: 2017 (3) s. 55-58.

Sorokowska A., Słowińska A., Zbieg A., Sorokowski P. (2014): Polska adaptacja testu Ten Item Personality Inventory (TIPI) - TIPI-PL). Wrocław.

Śliwak J., Zarzycka B. (2010): Wybrane korelaty przekonań postkrytycznych. „Analecta Cracoviensia" 42: 2010 s. 67-85.

Taylor J. (2018): The effects of faith on personality characteristics. https://www.mckendree.edu/academics/scholars/issue1/taylor.htm [dostęp: 28.06.2018].

Village A. (2005): Assesing belief about the Bible: a study among Anglican laity, ,Review of Religious Research" 46: 2005 (3) s. 243-254.

Village A. (2012): Biblical literalism among anglican clergy: what is the role of psychological type? „Mental Health, Religion and Culture” 15: 2012 (9) s. 955-968.

Village A. (2014): The relationship of psychological type to interpretations of Genesis among churchgoers in England. „Psychology of Religion and Spirituality” 6: 2014 (1) s. 72-82.

Village A., Francis L.J., The relationship of psychological type preferences to biblical interpretation, „Journal of Empirical Theology” 18: 2005 (1) s. 74-89.

Wilcox C., Francis L.J. (1997): Personality and religion among A level Religious Studies Students. „International Journal of Children s Spirituality” 1: 1997 s. 48-56.

Williams E. (2012): Religious affect and self-esteem: An analysis among teenagers in Wales. „The Welsh Journal of Psychology" 1: 2012 s. 11-17.

Williams E., Francis L.J. (2006): Personality and attitude toward Christianity among churchgoers: a replication. „Psychological Reports” 99: 2006 (1) s. 292-294.

Williams E., Robbins M., Francis L.J. (2005): When introverts ceased to be more religious: A study among 12- to 16-year-old pupils. „Journal of Beliefs and Values” 26: 2005 (1) s. 77-79.

Wulff D.M. (1991): Psychology ofreligion: classic and contemporary views. New York.

Youtika A., Joseph S,., Diduca D. (2007): Personality and religiosity in a Greek Christian Orthodox sample. „Mental Health, Religion and Culture” 2: 2007 (1) s. 71-74. 
Zarzycka B. (2012): Przekonania post-krytyczne a emocje względem Boga. Eksploracyjne badania na próbie polskiej. „Polskie Forum Psychologiczne” 17: 2012 (2) s. 344-353.

Zawadzki B., Strelau J., Szczepaniak P., Śliwińska M. (2007): Inwentarz Osobowości NEO-FFI Paula T. Costy Jri Roberta R. Mc Crea. Adaptacja polska. Warszawa.

Zieliński J. (2006): Analiza zróżnicowania stopnia spójności przekonań religijnych w grupie młodocianych przestępców. „Resovia Sacra. Studia Teologiczno-Filozoficzne Diecezji Rzeszowskiej” 13: 2006 s. 349-368.

Weadyseaw Chaim CSsR: dr psychologii Katolickiego Uniwersytetu Lubelskiego Jana Pawła II w Lublinie; zajmuje się psychologią komunikacji interpersonalnej, psychologią religii, psychologią kaznodziejstwa i homiletyką; pracuje jako misjonarz i rekolekcjonista; e-mail: wchaim@redemptor.pl. 